\title{
Comentário de Decisão Sobre
}

\section{Homologação de Divórcio Administrativo}

\section{Realizado no Japão Perante o Supremo}

\section{Tribunal Federal}

\section{Natália de Campos Aranovich, Advogada, Mestranda em Direito Processual Civil e Especialista em Direito Internacional pela Universidade Federal do Estado do Rio Grande do Sul}

No Brasil, como se sabe, o divórcio é ato judicial, porque para que produza efeitos só pode ser realizado perante o Poder Judiciário, conforme dispóe a Lei 6.515 de 26 de dezembro de 1977.

Já no Japão, o divórcio não é ato judicial, mas administrativo, que se realiza perante o Cartório do Registro Civil.

A decisão ora analisada versa sobre pedido de homologação de decisão administrativa de divórcio oriunda do Japão (processo registrado sob n. 6.399-0), proferida pelo Tribunal Pleno do Supremo Tribunal Federal, em 21.06.2000'1.

Nessa decisão o Supremo Tribunal Federal teve mais uma vez a oportunidade de pronunciar-se sobre o sentindo da expressão "sentença estrangeira" para fins do disposto no inciso I, do art. 102, da Constituição Federal.

Segundo o que foi narrado no acórdão, duas pessoas casaram em solo brasileiro e depois foram residir no Japão. A certidão de casamento realizada no Brasil foi devidamente homologada naquele país.

1 O acórdão foi publicado no Diário de Justiça da União no dia 15.09.00, p.119. 
Posteriormente, o casal requereu o divórcio amigável perante o Cartório de Registro Civil do Distrito de Itabashi, em Tóquio, no Japão.

Para que surtisse os devidos efeitos no Brasil os Autores requereram, perante o Supremo Tribunal Federal, a homologação do ato civil de divórcio realizado perante o Registro Civil Japonês.

Alegaram as partes que no Japão o requerimento de divórcio é formulado perante o Chefe do Executivo local, competente para o decreto. Alegaram ainda inúmeras decisões do Supremo Tribunal Federal no sentido de que quando a Constituição Federal no seu art.102, inciso I, alínea " $h$ " estabelece a competência do STF para processar e julgar a homologação de sentenças estrangeiras está inserido nesse conceito qualquer documento que a legislação de origem do país tenha como válido.

A Procuradoria Geral da República opinou pela intimação dos requerentes para que juntassem aos autos o certificado de divórcio, com a devida chancela consular e tradução oficial, pois o documento que havia sido juntado aos autos era uma certidão civil de divórcio e não uma sentença. Os requerentes cumpriram a decisão judicial, juntando a chancela do consulado e esclareceram que não havia no Japão o divórcio judicial e que o ato era realizado perante o Registro Civil. A Procuradoria Geral da República opinou pela não concessão da homologação, já que no Brasil o divórcio apenas pode ocorrer perante a autoridade judicial competente.

O Supremo Tribunal Federal, através do voto do Relator Marco Aurélio julgou procedente a homologação da "decisão administrativa de divórcio", realizada no Japão, por entender que a expressão "sentença estrangeira", a que dispõe a alínea "h", inciso I, art.120 da Constituição Federal, abrange também os documentos que "segundo a legislação de origem, tenham tal envergadura", como é o caso do ato administrativo de divórcio. Assim, tendo sido o divórcio realizado em conformidade com a legislação local do Japão, deveria ser homologado.

O Relator citou ainda inúmeros precedentes da Suprema Corte sobre a admissibilidade de homologação de atos administrativos de divórcio.

O cerne da discussão apresentada no acórdão versa sobre a abrangência do conceito de sentença estrangeira a que dispõe a alínea "h", do inciso I, do art.102 da Constituição Federal.

Questiona-se se a expressão sentença deve ser entendida apenas como decisão proferida por órgão jurisdicional, ou se pode ser também decisão administrativa, que, no caso em tela, é decisão de divórcio proferida por Registro Civil do Japão.

Antes de tudo cumpre-nos analisar o "caput" do art. $7^{\circ}$ da Lei de Introdução ao Código Civil (Decreto-lei 4.657 de 4 de setembro de 1942) que estabelece que a lei do país em que for domiciliada a pessoa determina as regras sobre o começo e o fim da personalidade, o nome, a capacidade e os direitos de família. Portanto, de acordo com esse artigo é a lei do domicílio do casal que rege o seu "estatuto pessoal". Assim, sendo as partes domiciliadas no Japão, quando do ato do divórcio, e ainda sendo naquele país o divórcio ato administrativo, não há nenhum óbice para que seja considerado legal o ato celebrado naquele país. 
Além disso, não se pode dizer que o divórcio realizado perante a autoridade administrativa fere a soberania ou a ordem pública brasileira.

A Constituição Federal, na alínea "h", do inciso I do art.102 estabelece que é competente o Supremo Tribunal Federal para processar e julgar originariamente "a homologação das sentenças estrangeiras e a concessão do exequatur às cartas rogatórias, que podem ser referidas pelo Regimento Interno a seu Presidente".

O art.15, da Lei de Introdução ao Código Civil, também fala sobre o processo de homologação de sentença estrangeira e na alínea "a" estabelece que será homologada a sentença estrangeira proferida por juiz competente, o que também foi fixado como requisito no art. 217, alíena "a" do Regimento Interno do STF.

Como se pode constatar, a lei brasileira dispõe que é suficiente que sentença seja proferida por juiz competente, não estabelecendo que precisa a decisão ser emanada de órgão do Poder Judiciário.

O art.483 do Código de Processo Civil dispõe ainda que: "a sentença proferida por Tribunal Estrangeiro não terá eficácia no Brasil se não depois de homologada pelo Supremo Tribunal Federal."

Não se pode interpretar literalmente o texto da lei e dizer que apenas têm eficácia as sentenças proferidas por autoridade judicial, pois se assim fizéssemos estaríamos excluindo do rol de homologação as decisões arbitrais internacionais, que não são emanadas pelo Órgão Judiciário, e que são amplamente reconhecidas pela Corte Superior para fins de homologação.

Se a decisão proferida no país estrangeiro obedeceu à legislação local, não pode o Supremo Tribunal Federal ignorar a soberania do país alienígena para regular os atos jurídicos que forem realizados sob a sua jurisdição.

O caso ora analisado versa sobre direito de família, que é regulado pela lei do domicílio. Se os cônjuges estavam residindo no Japão e o divórcio lá ocorreu, não se pode dizer que o ato não é válido no Brasil, porque feito corretamente de acordo com a lei local.

Além disso, a doutrina é concisa em afirmar que o termo sentença estrangeira abrange o ato administrativo do país alienígena.

Pontes de Miranda, comentando o art.483 do Código de Processo Civil discorre que 2 : "Na expressão sentenças estrangeiras compreendem-se todas as decisões judiciais que precisam ter eficácia alhures desde que decisão cível ou com eficácia cível. Incluem-se as decisões arbitrais e as autoridades administrativas, sem ter eficácia cível."

No mesmo sentido discorre Beat Walter Rechsteiner": "Se contiver os requisitos de uma sentença, deverá ser examinado exclusivamente a luz do direito brasileiro. Por essa razão, estão sujeitas à homologação, p.ex., decisões estrangeiras referentes a divórcios por mútuo consentimento, mesmo quando realizados no exterior, perante um órgão administrativo, em conformidade com o sistema jurídico do país de origem (...)".

2 De Miranda, Francisco Cavalcanti Pontes. Comentários ao Código de Processo Civil, Tomo VI, Ed. Forense, 1974, p.90.

${ }^{3}$ Rechesteiner, Beat Walter. Direito Internacional Privado, Ed. Saraiva, 1996, p.202. 
Haroldo Valadão também comenta, na sua obra o "Direito Internacional Privado", a admissibilidade de homologação, no Brasil, de atos administrativos de divórcio provenientes de países estrangeiros, dizendo que é concisa a jurisprudência no sentido de que é homologável decisão oriunda de autoridades civis, judiciais, administrativas e até legislativas.

Por estas razões, podemos afirmar que a decisão do Supremo Tribunal Federal foi proferida de acordo com a legislação brasileira e com os princípios de direito internacional.

\section{BIBLIOGRAFIA}

DE MIRANDA, Francisco Cavalcanti Pontes. Comentários ao Código de Processo Civil, Tomo VI, Ed. Forense, 1974, p.90

DE OLIVEIRA, José Lamartine Correa. Divórcio Consular Estrangeiro, in Revista dos Tribunais, vol. 576, ano 72, outubro de 1983, p.46-54.

MOREIRA, José Carlos Barbosa. Problemas Relativos à Litígios Internacionais, in Revista de Processo, n.65, ano 17, janeiro-março, 1992, p.144-161.

RECHSTEINER, Beat Walter. Direito Internacional Privado- Teoria e Prática, Ed. Saraiva, 1996.

VALLADÃO, HAROLDO. Direito Intermacional Privado. Rio de Janeiro, Ed. Freitas Bastos, 1983 . 
Comentário de Decisão sobre Homologação de Divórcio Adm. Realizado no Japão Perante o STF 161 